\title{
Preclinical and Clinical Aspects of Gene Therapy in Myocardial Infarction
}

\author{
Saurabh Bharti, Ashok Kumar Sharma, \\ Bhaskar Krishnamurthy and Dharamvir Singh Arya \\ Department of Pharmacology, \\ All India Institute of Medical Sciences, \\ New Delhi, \\ India
}

\section{Introduction}

Clinical occurrence of acute myocardial infarction (AMI) has substantially increased over the last decade. More than $50 \%$ of the cases of coronary heart disease alone are covered under AMI. Thus, the prevalence of AMI poses a serious health care burden, demanding for more strategic approaches. Exploration in molecular mechanisms underlying myocardial infarction (MI) has radically improved over the last half century. Novel pathways have not only provided in-depth knowledge of mechanistic approach to understand the pathophysiology of MI but also offer new strategies for its treatment. Currently, polypharmacy comprising $\beta$-blockers, angiotensin converting enzyme (ACE) inhibitors, angiotensin receptor blockers (ARB) and aspirin are generally adopted for treating patients of MI. Surgical interventions include stenting procedures and percutaneous coronary interventions. Despite availability of these pharmacological and surgical therapies, they are associated with limitations encompassing side effects, recurrence, non-compliance and interactions with other drugs. The early mortality rate from AMI is about $30 \%$, with more than half of these deaths occurring before the stricken individual reaches the hospital (AHA report, 2003). Therefore looking towards the 21st century, now the question arises, can we bring an ideal therapy for treatment of human MI where all the side effects, interaction and compliance issues can be eliminated? The answer might lie in an emerging area known as gene therapy. Cardiovascular gene therapy is one of those areas where administration of a particular gene would result in long term gene expression and preclude the heart from various insults. In general an ideal gene therapy should have multifaceted approach such as 1) It should be specific for the myocardial tissue 2) it should not cause potential adverse effects 3) it should not disrupt the vital genes 4) it should not increase the risk of other diseases such as predisposition to cancer and finally 5) it should be long enough to sustain and to prevent any recurrence of the disease. Most recent exciting development in gene therapy includes formation of new blood vessels and improved blood flow to ischemic tissues induced by growth factors such as VEGF, HGF, FGF and PDGF. Furthermore, improved calcium handing through SERCA2a, phospholamban, parvalbumin and S100A1 proteins offers a viable and attractive approach in the treatment of heart failure. In addition, modulation of $\beta$-adrenergic receptor signaling through $\beta 2$ adrenergic receptor overexpression, GRK2/ $\beta$ ARKct and Adenlyl cyclase 6 has yielded encouraging results in 
experimental models of MI. Thereafter, various cardiovascular diseases where gene therapy has made its mark in pre-clinical studies are angiogenesis for myocardial ischemia, restenosis and bypass graft failure. Gene therapy with its specificity on myogenesis, cell cycle activation anti-oxidant and anti-apoptotic pathways upregulates the cellular defense system and provides augmented cardioprotective response to injury and cardiac remodeling. Success in animal models and in early phases of clinical trials of gene therapy in myocardial ischemic reperfusion setting further validates imminent use of gene therapy. Mechanistically, gene therapy for MI must be aimed at activating key molecular pathways in myocardium that significantly alleviate the cardiac injury by inducing neo-angiogenesis, strengthening anti-oxidant status of the myocardium, inhibiting necrosis/apoptotic pathways, inhibiting mitochondrial permeability transition pore and most importantly preserving the integrity of myocardium (remodeling).

This chapter will basically focus on the significant results of gene therapy obtained in myocardial ischemia reperfusion injury in pre-clinical studies, phase I/II clinical trials and their future implications to make gene therapy a completely bench to bed-side approach.

\section{Preclinical aspect}

\subsection{Role of angiogenesis in gene therapy}

Perhaps, the most highly investigated and promising application of gene therapy which has shown indispensable results in animal models of myocardial infarction is angiogenesis. Angiogenesis occurs as a result of multiple growth factors participating in the formation of new blood vessels. Growth factors including vascular endothelial growth factor (VEGF), hepatocyte growth factor (HGF), fibroblast growth factor (FGF) and platelet derived growth factor (PDGF), either alone or in combination, result in induction of angiogenesis. Therefore gene therapy can act in very specific and targeted manner, i.e. either to activate the pathways which up-regulate endogenous growth factors like hypoxia inducible factor-1 alpha (HIF-1a), to inhibit endogenous anti-angiogenic processes or to induce growth factors exogenously. The various angiogenic growth factors which have shown significant results in animal models of myocardial infarction are as follows:

\subsubsection{VEGF}

Family comprises of five isoforms viz. VEGF-A, VEGF-B, VEGF-C, VEGF-D and placental growth factor. The major function of VEGF is to regulate coronary vasculature development, blood vessel physiology, vasodilation, proliferation and migration of endothelial and smooth muscle cells.

\subsubsection{HGF}

HGF shows its diversified action through coupling with c-Met receptor following tyrosine kinase activation. HGF is a pleiotropic factor which promotes neo-vascularization, migration and proliferation of endothelial cells and inhibits apoptosis. In addition; morphogenesis, mitogenesis, motogenesis and neurite extension are the other effects shown by HGF.

\subsubsection{FGF}

Family comprises of 22 distinct polypeptide growth factors and seven single-chain tyrosine receptor kinases. FGF is also known as heparin binding growth factor because of its higher affinity towards heparin and heparan sulfate. FGF displays its activities through autophosphorylation via dimerization of its receptor. FGF actively participates in both the 
phases of angiogenesis/arteriogenesis i.e. early invasive phase and late maturative phase. Functionally, it is involved in migration and proliferation of endothelial and smooth muscle cells, production of proteases and vessel maturation.

\subsubsection{PDGF}

Family comprises of five isoforms viz. PDGF-A, PDGF-B, PDGF-C, PDGF-D and PDGF-AB heterodimer; and acts through two distinct receptors namely $\alpha$ and $\beta$. Its function is to regulate cell growth and division. PDGF is a potent mitogen for smooth muscle cells of mesenchymal origin.

\begin{tabular}{|c|c|c|c|}
\hline $\begin{array}{l}\text { Growth } \\
\text { Factors }\end{array}$ & Species & Outcome & References \\
\hline VEGF-165 & $\begin{array}{l}\text { Rats, } \\
\text { rabbits }\end{array}$ & $\begin{array}{l}\text { Increased neovascularization and } \\
\text { improved fractional shortening after MI }\end{array}$ & $\begin{array}{l}\text { Bull et al., 2003; } \\
\text { Hao et al., 2007; } \\
\text { Ruixing et al., } \\
2006 .\end{array}$ \\
\hline VEGF-165 & Porcine & $\begin{array}{l}\text { Increased myocardial blood flow, } \\
\text { increased vasodilation with adenosine, } \\
\text { improved wall thickening and strain, } \\
\text { improved wall motion, increased } \\
\text { ejection fraction and increased } \\
\text { myocardial viability }\end{array}$ & $\begin{array}{l}\text { Choi et al., 2006; } \\
\text { Ferrarini et al., } \\
\text { 2006; Jacquier et } \\
\text { al., 2007; Tio et al., } \\
\text { 1999; Zhang et al., } \\
\text { 2002. }\end{array}$ \\
\hline VEGF-121 & $\begin{array}{c}\text { Rats, } \\
\text { porcine }\end{array}$ & $\begin{array}{c}\text { Increased collateral circulation } \\
\text { following MI }\end{array}$ & $\begin{array}{l}\text { Lee et al., 2000; } \\
\text { Mack et al., 1998. }\end{array}$ \\
\hline $\begin{array}{l}\text { VEGF- } \\
\text { B186 }\end{array}$ & $\begin{array}{l}\text { Pigs, } \\
\text { rabbits }\end{array}$ & $\begin{array}{l}\text { improved myocardial perfusion and } \\
\text { ejection fraction }\end{array}$ & $\begin{array}{l}\text { Lahteenvuo et al., } \\
2009\end{array}$ \\
\hline VEGF-C & Piglets & $\begin{array}{l}\text { augmented collateral formation and } \\
\text { decreased wall thickening after MI }\end{array}$ & Patila et al., 2006 \\
\hline VEGF-D & Porcine & $\begin{array}{l}\text { improved perfusion when administered } \\
\text { through a catheter mediated intra } \\
\text { myocardial gene transfer method }\end{array}$ & $\begin{array}{l}\text { Rutanen et al., } \\
\quad 2004\end{array}$ \\
\hline $\begin{array}{l}\text { VEGF } \\
\text { gene } \\
\text { constructs }\end{array}$ & $\begin{array}{l}\text { Rat, } \\
\text { mouse }\end{array}$ & $\begin{array}{l}\text { Reduced infarct size and induction of } \\
\text { angiogenesis }\end{array}$ & $\begin{array}{c}\text { Lee et al., 2003; Su } \\
\text { et al., 2002; } \\
\text { Yockman et al., } \\
2009\end{array}$ \\
\hline HGF & Rats, dogs & Induction of angiogenesis & $\begin{array}{l}\text { Aoki et al., 2000; } \\
\text { Funatsu et al., } \\
\text { 2002; Wang et al., } \\
\text { 2006a }\end{array}$ \\
\hline HGF & $\begin{array}{l}\text { Mice, } \\
\text { Swine, } \\
\text { canine, } \\
\text { porcine }\end{array}$ & $\begin{array}{l}\text { Improved remodeling, decreased } \\
\text { apoptosis, improved mobilization of } \\
\text { stem cells for cardiac repair, decreased } \\
\text { fibrotic scar formation and improved } \\
\text { contractility of the heart }\end{array}$ & $\begin{array}{l}\text { Ahmet et al., 2002; } \\
\text { Ahmet et al., 2003; } \\
\text { Cho et al., 2008; } \\
\text { Jayasankar et al., } \\
\text { 2003; Jin et al., } \\
\text { 2004; Li et al., } \\
\text { 2003; Taniyama et } \\
\text { al., 2002; Yang et } \\
\text { al., 2007; Yang et } \\
\text { al., } 2010\end{array}$ \\
\hline
\end{tabular}




\begin{tabular}{|c|c|c|c|}
\hline $\begin{array}{l}\text { Growth } \\
\text { Factors }\end{array}$ & Species & Outcome & References \\
\hline $\begin{array}{c}\text { HGF + } \\
\text { ultrasound } \\
\text { mediated } \\
\text { micro } \\
\text { bubble } \\
\text { destruction }\end{array}$ & Rat & $\begin{array}{c}\text { Increased angiogenesis, limitation of } \\
\text { infarct size, and prevention of LV } \\
\text { remodeling }\end{array}$ & Kondo et al., 2004 \\
\hline FGF & Pig & $\begin{array}{l}\text { Improved blood flow and MI by } \\
\text { enhancing collateral formation }\end{array}$ & Post et al., 2006 \\
\hline FGF-2 & Pigs & $\begin{array}{c}\text { Improved LV functions and increased } \\
\text { arteriogenesis }\end{array}$ & $\begin{array}{l}\text { Horvath et al., } \\
2002\end{array}$ \\
\hline FGF-4 & Pigs & $\begin{array}{c}\text { increased perfusion and decreased LV } \\
\text { dysfunction }\end{array}$ & Gao et al., 2004 \\
\hline FGF-5 & Pigs & $\begin{array}{l}\text { Improved blood flow, Reduced pacing- } \\
\text { induced regional myocardial } \\
\text { dysfunction }\end{array}$ & $\begin{array}{l}\text { Giordano et al., } \\
\text { 1996; Suzuki et al., } \\
2005\end{array}$ \\
\hline PDGF-AB & Rat & $\begin{array}{l}\text { Promoted angiogenesis and minimized } \\
\text { the extent of myocardial infarction }\end{array}$ & $\begin{array}{l}\text { Edelberg et al., } \\
2002\end{array}$ \\
\hline $\begin{array}{l}\text { PDGF }+ \\
\text { basic FGF }\end{array}$ & Rat & $\begin{array}{l}\text { Promoted angiogenesis with more } \\
\text { stable capillaries }\end{array}$ & Hao et al., 2004a \\
\hline $\begin{array}{l}\text { PDGF-BB } \\
+ \text { VEGF- } \\
\text { A165 }\end{array}$ & Rat & $\begin{array}{l}\text { Stimulated angiogenesis both at the } \\
\text { capillary and arteriolar levels and } \\
\text { transiently counteracted cardiac } \\
\text { remodelling after MI }\end{array}$ & Hao et al., 2004b \\
\hline PDGF & Rat & Improved cardiac function & Zheng et al., 2004 \\
\hline PDGF & Rats & $\begin{array}{l}\text { Improved post-infarction ventricular } \\
\text { function without pulmonary toxicity }\end{array}$ & Hsieh et al., 2006 \\
\hline $\begin{array}{l}\text { PDGF-BB } \\
+ \text { FGF-2 }\end{array}$ & Pigs & $\begin{array}{c}\text { Enhanced myocardial collateral growth } \\
\text { and significantly restored myocardial } \\
\text { perfusion and function }\end{array}$ & Lu et al., 2007 \\
\hline PDGF-BB & Rats & Significantly decreased MI & $\begin{array}{l}\text { Krausgrill et al., } \\
2009\end{array}$ \\
\hline
\end{tabular}

Table 1. The examples of various growth factors in myocardial infarction.

\subsection{Role of oxidative stress in gene therapy}

The human cells are replete with a number of molecules that function as antioxidants, i.e. which protect the cells from a group of molecules known as pro-oxidants. Anti-oxidants are molecules that are capable of inhibiting the oxidation of other molecules. In this process, they themselves get oxidized. On the other hand, pro-oxidants either generate free radicals or inhibit the anti-oxidant systems, thus predisposing the cell to oxidative damage. Oxidative stress represents a condition characterized by an imbalance between the prooxidant and anti-oxidant systems within the cell, leading to oxidative damage to the cell; ultimately leading to lipid peroxidation, protein degradation and DNA damage and has been implicated in a vast variety of disorders; atherosclerosis, diabetes, myocardial infarction, myocardial ischemia-reperfusion injury, hypertension, heart failure, 
cardiomyopathy and rheumatoid arthritis being just a few of them. Examples of ROS include radicals like superoxide, hydroxyl, alkoxyl and peroxyl; and non-radicals like hydrogen peroxide, hypochlorous acid and organic hydroperoxides.

The observation that the level of antioxidants is increased during periods of oxidative stress has led to the finding that the synthesis of antioxidants is increased at the times of oxidative stress. This has led to the concept that administration of genes for antioxidants can combat the role of oxidative stress and thus protect cells and tissues from damage. Various studies and clinical trials have been carried out in this regard and the role of gene therapy for antioxidants in myocardial ischemia prevention has been established in animal models. The intramyocardial delivery of heme oxygenase-1(HO-1) into the left ventricle of rats using AAVs (Adeno-Associated Virus) several weeks before myocardial infarction resulted in approximately $80 \%$ decrease in infarct size in association with decreases in oxidative stress, inflammation, and interstitial fibrosis and was accompanied by postinfarction recovery and normalization of ventricular dimensions (Melo et al., 2002). Similar results were obtained after transfer of gene for extracellular superoxide dismutase (EC-SOD); wherein recombinant adeno virus transfer into the myocardium of conscious rabbits of the gene encoding EC-SOD, three days before the induction of myocardial ischaemia by a 30-minute coronary artery occlusion using a balloon occluder, afforded cardioprotection with a decrease in the region at risk and infarct size as compared to controls ( $\mathrm{Li}$ et al., 2001). Its intracellular counterparts (Mn-SOD and $\mathrm{Cu} / \mathrm{Zn}-\mathrm{SOD}$ ) have also been shown to decrease infarct size following ischaemia-reperfusion injury, as well as decrease apoptosis and delay induction of NF-kB (Michiels et al., 1994; Chen et al., 1998). Thioredoxins are potent antioxidants that decrease p38MAPK signaling and superoxide anion generation and hence, combat oxidative stress. Trx-1 gene therapy administered post-MI has been shown to promote angiogenesis, decrease apoptosis, reduce ventricular remodeling, and improve ejection fraction in diabetic rats (Samuel et al., 2010). Below are mentioned some important anti-oxidants which have shown remarkable results in experimental models of myocardial infarction.

\subsubsection{HEME oxygenase-1 (HO-1)}

Heme oxygenase cleaves the heme ring at the alpha-methene bridge to form biliverdin, iron and carbon monoxide. Its activity is highest in the spleen, where old RBCs are sequestered and destroyed, leading to liberation of hemoglobin and its subsequent separation into heme and globin. It has three isoforms: HO-1 (which is also referred to as heat-shock protein $32 \mathrm{~K}$ or HSP-32K) is inducible in response to oxidative stress, hypoxia, heavy metals, cytokines and a variety of other compounds. HO-1 has also been suggested to induce VEGF formation. HO-2 is constitutive and is expressed under normal or homeostatic conditions. HO-3, unlike the other two isoforms, is not catalytically active, but has been postulated to work in oxygen sensing. AAV delivery of HO-1 performed in MI-rat models demonstrated an increase in cardiac remodeling and an improvement in cardiac function (Melo et al., 2002). Studies performed in animals with human heme oxygenase- 1 (hHO-1) administered 6 -8 weeks prior to induction of ischaemia resulted in decreased mortality at 1 year, along with a decrease in infarct size, reduction in ventricular thinning, decreased inflammation stress and interstitial fibrosis, decreased lipid peroxidation, and was accompanied by postinfarction recovery and normalization of ventricular functions (Melo et al., 2002). 


\subsubsection{Superoxide dismutase (SOD)}

The enzyme superoxide dismutase (EC: 1.15.1.1) was first discovered by Fridowich and McCord (McCord \& Fridovich, 1988). It scavenges the superoxide (O-2.) radical and causes its dismutation into water and hydrogen peroxide by the following reaction -

$$
2 \mathrm{O}^{-2}+2 \mathrm{H} \rightarrow \mathrm{H}_{2} \mathrm{O}_{2}+\mathrm{O}_{2}
$$

The enzyme has three isoforms - 1. Cytosolic (Cu/Zn-SOD) or SOD-1, dependent on copper and zinc (Cao, et al., 2008). 2. Mitochondrial (Mn-SOD) or SOD-2, dependent on manganese (Borgstahl, et al., 1996) and 3. Extracellular (EC-SOD) or SOD-3. The genes for these are located on chromosomes 21q22.1, 6q25.3 and 4p15.3 respectively. $\mathrm{Cu} / \mathrm{Zn}-\mathrm{SOD}$ is dimeric and the other two are tetrameric in structure. All of them have improved left ventricular function and increased survival in rat ischaemia-reperfusion models (Michiels et al., 1994, Chen et al., 1998; Li, et al., 2001). Studies on EC-SOD in rat ischaemia-reperfusion models have demonstrated decreased myocardial stunning and infarct size (Li et al., 2001). Mn-SOD and eNOS administered together have also led to decreased infarct size in animal ischaemiareperfusion models (Abunasra et al., 2001).

\subsubsection{Thioredoxins}

Thioredoxins are another group of antioxidant proteins that are ubiquitously found in many organisms and are encoded by the TNX gene in humans (Wollman et al., 1988). They have a $12 \mathrm{kDa}$ tertiary structure, that contains a dithiol-disulfide active site and facilitate the reduction of other proteins by a cysteine thiol-disulfide exchange. The amino acid sequence of thioredoxins is characterized by two vicinal cysteines in a CXXC motif which provide the enzyme the ability to reduce various substrates, such as ribonucleases, chorionic gonadotrophins, coagulation factors, glucocorticoid receptors and insulin. The thioredoxins also act as electron donors to peroxidases and ribonucleotide reductase (Arner \& Holmgren, 2000).

The summary of the researches carried out on antioxidant gene therapy in $\mathrm{MI}$ is summarized in the table 2.

\begin{tabular}{|l|l|l|l|}
\hline Gene & Model & Outcome & References \\
\hline HO-1 & Rat I/R & $\begin{array}{l}\text { Decrease in infarct size. Decrease in } \\
\text { oxidative stress, inflammation and } \\
\text { interstitial fibrosis. Post-infarction } \\
\text { recovery with normalization of } \\
\text { ventricular dimensions }\end{array}$ & Melo et al., 2002 \\
\hline SOD & Rat I/R & $\begin{array}{l}\text { Decreased stunning. Decreased infarct } \\
\text { size following I/R injury. Improved left } \\
\text { ventricular function. Increased survival }\end{array}$ & $\begin{array}{l}\text { Michiels et al., } \\
\text { 1994 \& Chen et al., } \\
\text { 1998, Li et al., 2001 }\end{array}$ \\
\hline TRX-1 & $\begin{array}{l}\text { Post-MI } \\
\text { diabetic } \\
\text { rats }\end{array}$ & $\begin{array}{l}\text { Angiogenesis. Decreased apoptosis. } \\
\text { Decreased ventricular remodeling. } \\
\text { Improved ejection fraction. }\end{array}$ & Samuel et al., 2010 \\
\hline SPHK1 & Rats & $\begin{array}{l}\text { Improved systolic and diastolic } \\
\text { functions of the heart and improved } \\
\text { peak contraction velocity }\end{array}$ & Jin et al., 2007 \\
\hline
\end{tabular}

Table 2. Examples of various anti-oxidants studied for gene therapy. 


\begin{tabular}{|c|c|c|c|}
\hline Gene & Species & Outcome & Reference \\
\hline Bcl-2 & Rabbits & $\begin{array}{l}\text { Reduced apoptosis, reduced ventricular } \\
\text { dilatation and decreased wall thinning }\end{array}$ & $\begin{array}{l}\text { Chatterjee et al., } \\
2002\end{array}$ \\
\hline $\begin{array}{l}\text { Apoptosis } \\
\text { repressor } \\
\text { gene }\end{array}$ & Rabbits & $\begin{array}{l}\text { Inhibition of apoptosis, decreased LV } \\
\text { dilatation with preserved ejection fraction }\end{array}$ & $\begin{array}{l}\text { Chatterjee et al., } \\
2003\end{array}$ \\
\hline $\begin{array}{l}\text { Cardio- } \\
\text { trophin-1 } \\
(\mathrm{CT}-1) \\
\end{array}$ & Mouse & $\begin{array}{l}\text { Decreased apoptosis, decreased infarct } \\
\text { size, decreased caspase- } 3 \text { activation and } \\
\text { improved ventricular pressure indices }\end{array}$ & Ruixing et al., 2007 \\
\hline Akt & Rats & $\begin{array}{l}\text { Limitation of infarct size, improved } \\
\text { myocardial contractility and reduced } \\
\text { infarct size }\end{array}$ & $\begin{array}{l}\text { Cittadini et al., 2006; } \\
\text { Miao et al., } 2000\end{array}$ \\
\hline $\begin{array}{l}\text { sTNFR1 } \\
\text { (TNF-a } \\
\text { antagonist) }\end{array}$ & Mice & $\begin{array}{l}\text { Reduced infract size and improved cardiac } \\
\text { function }\end{array}$ & Sugano et al., 2004 \\
\hline HSP 20 & Rats & $\begin{array}{l}\text { Improved LV end systolic and end } \\
\text { diastolic pressures, reduced apoptosis and } \\
\text { decreased infarct size }\end{array}$ & Zhu et al., 2005 \\
\hline HSP 70 & Rabbits & Decreased infarct size & Okubo et al., 2001 \\
\hline HSP 72 & Rats & $\begin{array}{l}\text { Decreased apoptosis and } \\
\text { prevented MI }\end{array}$ & Suzuki et al., 2002 \\
\hline $\begin{array}{l}\text { Kallikrein } \\
\text { gene }\end{array}$ & Rats & $\begin{array}{l}\text { Decreased apoptosis, endothelial } \\
\text { dysfunction and preservation of cardiac } \\
\text { output }\end{array}$ & Agata et al., 2002 \\
\hline \begin{tabular}{|l|} 
Sonic \\
hedgehog \\
homolog \\
(Shh) \\
\end{tabular} & Mice, Rats & $\begin{array}{l}\text { Preserved ventricular function by } \\
\text { enhancing neovascularization, reduced } \\
\text { apoptosis and fibrosis }\end{array}$ & Kusano et al., 2005 \\
\hline $\begin{array}{l}\text { Troponin I } \\
\text { type } 3 \\
\text { interacting } \\
\text { kinase }\end{array}$ & Mice & $\begin{array}{l}\text { Decreased MI and inhibition of } \\
\text { remodeling }\end{array}$ & Lai et al., 2008 \\
\hline $\begin{array}{l}\text { Leukemia } \\
\text { inhibitory } \\
\text { factor (LIF) } \\
\end{array}$ & Rats & Preservation of rat myocardium post-MI & Berry et al., 2004 \\
\hline \begin{tabular}{|l|} 
Cluster of \\
Differentiati \\
on 151 \\
(CD151)
\end{tabular} & $\begin{array}{l}\text { Pigs and } \\
\text { rats }\end{array}$ & $\begin{array}{l}\text { Promoted neovascularization and } \\
\text { improved cardiac function }\end{array}$ & $\begin{array}{l}\text { Wang et al., 2006b, } \\
\text { Zuo et al., } 2009\end{array}$ \\
\hline $\begin{array}{l}\text { p38 kinase + } \\
\text { active MAP } \\
\text { kinase } \\
\text { kinase } 3 \mathrm{~b}\end{array}$ & Rats & $\begin{array}{l}\text { Reduced infarct size, decreased apoptosis, } \\
\text { increased capillary density, decreased } \\
\text { fibrosis and improved ejection fraction }\end{array}$ & $\begin{array}{l}\text { Tenhunen et al., } \\
2006\end{array}$ \\
\hline
\end{tabular}

Table 3. The examples of various proteins involved in apoptosis studied for gene therapy. 


\subsection{Role of apoptosis in gene therapy}

Apoptosis means programmed cell death. It is a physiological phenomenon that normally occurs during the embryonic development in humans and also serves as a protective response in case of irreparable DNA damage to avoid the multiplication of defective cells. Two various pathways are involved in induction of apoptosis. The extracellular pathway involves stimulation of death receptors that transduce signals to the nucleus to activate caspases. The intracellular pathway involves increase in the permeability of the inner mitochondrial membrane that causes leakage of pro-apoptotic molecules like cytochrome $\mathrm{c}$ into the cytoplasm that directly activate the caspases. The end-result is the activation of caspases that digest the protein cytoskeleton of the cell. The distinct family of Bcl proteins is involved in apoptosis, with Bcl-2 and Bcl-x acting as anti-apoptotic factors; while Bax and Bak act as pro-apoptotic factors.

The pathways of apoptosis provide an excellent target for gene therapy as inhibition of apoptosis allows the cells to survive. Gene therapies with pro-apoptotic molecules and genes that transcribe proteins that suppress the anti-apoptotic proteins have been tried in animal models with sufficiently encouraging results, which are yet to be supplemented by results from clinical trials (Table 3 ).

\subsection{Role of calcium signaling in gene therapy}

The handling of $\mathrm{Ca}^{2+}$ during excitation-contraction (EC) coupling is an important feature of the cardiomyocyte contraction. In cardiomyocytes, EC coupling begins with the initiation of action potential, whereby, $\mathrm{Ca}^{2+}$ enters the cell through voltage-gated L-type $\mathrm{Ca}^{2+}$ channels and triggers the ryanodine receptor $(\mathrm{RyR})$ to extrude $\mathrm{Ca}^{2+}$ from the sarcoplasmic reticulum (SR) into the cytosol. This $\mathrm{Ca}^{2+}$ induced $\mathrm{Ca}^{2+}$ release trigger is a crucial step in cardiomyocyte contraction through $\mathrm{Ca}^{2+}$ binding to troponin $\mathrm{C}$ within the myofilaments of the sarcomere. Furthermore, it is again imperative to remove the $\mathrm{Ca}^{2+}$ from the cytosol to initiate the relaxation of sarcomere which is mainly dependent on sarco/endoplasmic reticulum $\mathrm{Ca}^{2+}$ ATPase 2a (SERCA2a) and sarcolemmal $\mathrm{Na}^{+}-\mathrm{Ca}^{2+}$ exchanger (NCX). Moreover, distortion of $\mathrm{Ca}^{2+}$ handling in cardiomyocytes occurs due to decreased SR $\mathrm{Ca}^{2+}$ store and a prolonged $\mathrm{Ca}^{2+}$ transient, which is generally a consequence of increased NCX, reduction in SERCA2a, decreased phospholamban (PLN)/SERCA2a ratio and increased open probability of the RyR. In addition, these abnormalities in $\mathrm{Ca}^{2+}$ handling cause dysfunctional contractile performance and may increase the risk of cardiac arrhythmias and cardiac remodeling. Because myocardial contractility is dependent on ventricular $\mathrm{Ca}^{2+}$ handling, therefore, genetic modification of molecules involved in dysfunctional cardiomyocyte $\mathrm{Ca}^{2+}$ handling could be a viable and attractive target in the treatment of heart failure. The major proteins which participate in handling of calcium during cardiomyocyte contraction are discussed briefly:

\subsubsection{Sarco/endoplasmic reticulum Ca2+-ATPase (SR Ca ${ }^{2+}$-ATPase, SERCA)}

SERCA, a calcium ATPase (type P-ATPase) exists in the SR within muscle cells and transfers $\mathrm{Ca}^{2+}$ from the cytosol of the cell to the SR at the cost of ATP hydrolysis during muscle relaxation. There are three isoforms of SERCA viz. SERCA1-3, which have been shown to play distinct roles in various cells. Of the three isoforms available SERCA2 plays a significant role in calcium handling during myocyte contraction. Of note, SERCA2a activity is reduced in heart failure, resulting in decreased calcium uptake and impaired relaxation. Furthermore, SERCA2a activity in myocytes is controlled by phospholamban (PLN), a small 
inhibitory peptide that inhibits SERCA2a in its dephosphorylated form; whereas phosphorylated PLN reduces this inhibition. Therefore, SERCA2a gene therapy would aim to increase SERCA2a activity, which in turn would increase calcium uptake and thus improve diastolic relaxation. In addition it would also increase contractile reserve because of higher SR calcium concentration.

\subsubsection{Phospholamban (PLN)}

PLN is a protein which is encoded by the PLN gene in humans. The important function of PLN is to regulate $\mathrm{Ca}^{2+}$ pump in skeletal and cardiac muscle cells. It has been observed that dephosphorylated phospholamban (PLB) inhibits SERCA2a activity, while proteins such as calcium-calmodulin-dependent protein kinase (CAMkinase) and protein kinase A (PKA) cause phosphorylation of PLB to relieve this inhibition. This cross-talk between PLB and SERCA2a controls the calcium content of the SR and normal myocardial contractility. The role of PLB in cardiac $\mathrm{Ca}^{2+}$ handling has been elucidated through PLB-knockout mice; that displayed enhanced $\mathrm{Ca}^{2+}$ kinetics and showed significantly increased cardiac contractility. Paradoxically, PLB overexpressing mice showed impaired $\mathrm{Ca}^{2+}$ cycling associated with depressed contractile parameters. Thus, PLB plays a nodal role in the regulation of SR $\mathrm{Ca}^{2+}$ homeostasis through its potent action on SERCA2a activity which in turn leads to slower cytosolic $\mathrm{Ca}^{2+}$ decay and prolonged diastolic relaxation.

\subsubsection{Parvalbumin}

Parvalbumin is a calcium-binding albumin protein that resides in fast-contracting muscles (highest levels), in the brain and some endocrine tissues. Gene therapy with parvalbumin, a $\mathrm{Ca}^{2+}$ sequestering protein, potentially provides an energy-independent removal of cystosolic calcium and thus improves the functioning of the heart. Adenovirus (AdV) parvalbumin delivery in hypothyroid rat hearts led to an increased rate of calcium removal and an improved rate of diastolic relaxation. Thus, parvalbumin may constitute a potentially attractive mode of correcting the prolonged diastolic $\mathrm{Ca}^{2+}$ decay generally seen in heart failure without further energy deprivation. Likewise, AdV-parvalbumin delivery to isolated cardiomyocytes from dog hearts after thoracic aortic coarctation resulted in improved relaxation kinetics but depressed sarcomere shortening at higher parvalbumin concentrations. This was probably due to inadvertant calcium removal during systole. Although potentially promising target for gene therapy in heart failure, further studies addressing the impact of long-term parvalbumin expression in relevant models of HF is warranted to clarify its role.

\subsubsection{S100A1}

S100A1 belongs to the S100 protein family (the largest $\mathrm{Ca}^{2+}$ binding protein subfamily) and appears to play multiple and inimitable roles in cardiomyocyte $\mathrm{Ca}^{2+}$ handling. It is highly expressed in the heart and localized to SR, sarcomere and the mitochondria. It is demonstrated by some researchers that myocardial levels of S100A1 are decreased in heart failure. So, S100A1 gene delivery to cardiomyocytes may result in an increased isometric contraction followed by an increase in the amount of $\mathrm{Ca}^{2+}$ pumped into the SR. Adrenergic receptor stimulation in the presence of S100A1 overexpression enhanced maximal contractile performance. Furthermore, S100A1 decreases the $\mathrm{Ca}^{2+}$ concentration during diastole and augments $\mathrm{Ca}^{2+}$ release during systole by regulating both RyR and SERCA2a. In addition, S100A1 also augments SERCA2a activity during the relaxation phase and improves diastolic relaxation. 


\begin{tabular}{|c|c|c|c|}
\hline $\begin{array}{l}\text { Target } \\
\text { Gene }\end{array}$ & Species & Outcome & References \\
\hline $\begin{array}{l}\text { SR CA }^{2+} \\
\text { ATPASE }\end{array}$ & $\begin{array}{l}\text { Isolated } \\
\text { cardio } \\
\text { myocytes } \\
\text { Rats }\end{array}$ & $\begin{array}{l}\text { In vitro restored the contractile function of } \\
\text { cardiomyocytes isolated from failing human } \\
\text { hearts. } \\
\text { Improved systolic and diastolic function } \\
\text { along with improved survival ( } 63 \% \text { versus } \\
9 \% \text { ). } \\
\text { Improved left ventricular systolic pressure, } \\
\text { enhanced ventricular pressure rise decline } \\
\text { (dp/dt), normalized rate of isovolumic } \\
\text { relaxation. } \\
\text { Adenoviral gene transfer of SERCA2a in a } \\
\text { rat model of heart failure (aortic banding) } \\
\text { improved left ventricular function. }\end{array}$ & $\begin{array}{l}\text { del Monte et al., } \\
\text { 2001a } \\
\text { del Monte et al., } \\
2001 b \\
\text { Miyamoto et al., } \\
2000\end{array}$ \\
\hline $\begin{array}{l}\text { PHOSPHO } \\
\text { LAMBAN }\end{array}$ & $\begin{array}{l}\text { Mice } \\
\text { Human } \\
\text { myocardial } \\
\text { cells } \\
\text { Silencing of } \\
\text { PLB sheep } \\
\text { Mice }\end{array}$ & $\begin{array}{l}\text { Impaired } \mathrm{Ca}^{2+} \text { cycling associated with } \\
\text { depressed contractile parameters . } \\
\text { Improvement in contraction and relaxation } \\
\text { velocities. } \\
\text { Improved SERCA activity, improved systolic } \\
\text { and diastolic LV function. } \\
\text { Enhanced } \mathrm{Ca}^{2+} \text { kinetics. }\end{array}$ & $\begin{array}{l}\text { Kadambi et al., } 1996 \\
\text { del Monte et al., } 2002 \\
\text { Kaye et al., } 2007 \\
\text { Kiriazis et al., } 2000\end{array}$ \\
\hline $\begin{array}{l}\text { PARV } \\
\text { ALBUMIN }\end{array}$ & $\begin{array}{l}\text { Dog cardio } \\
\text { myocytes }\end{array}$ & $\begin{array}{l}\text { Improved relaxation kinetics but depressed } \\
\text { sarcomere shortening at higher parvalbumin } \\
\text { concentrations. }\end{array}$ & Hirsch et al., 2004 \\
\hline S100A1 & $\begin{array}{l}\begin{array}{l}\text { Cardiomyoc } \\
\text { ytes }\end{array} \\
\text { Mice } \\
\text { Intracoronar } \\
\text { y delivery } \\
\text { of AAV6- } \\
\text { S100A1Post- } \\
\text { MI rat heart } \\
\text { AdV- } \\
\text { mediated } \\
\text { S100A1 gene } \\
\text { transfer to } \\
\text { failing rat } \\
\text { cardiomyocy } \\
\text { tes }\end{array}$ & $\begin{array}{l}\text { Increase of isometric contraction followed by } \\
\text { an increase in the amount of } \mathrm{Ca}^{2+} \text { pumped } \\
\text { into the SR. } \\
\text { Substantially worsened LV function, } \\
\text { transaortic constriction and MI with } \\
\text { significantly lower survival. } \\
\text { LV dysfunction and HF was evident initially } \\
\text { and } 2 \text { months after gene delivery, S100A1- } \\
\text { treated HF rats presented with significantly } \\
\text { enhanced cardiac function and a reversal of } \\
\text { LV remodeling compared to control HF rats. } \\
\text { Restoration of disturbed } \\
\text { Ca }{ }^{2+} \text { handling by increasing reuptake of SR } \\
\text { Ca }{ }^{2+} \text { during the relaxation phase and a } \\
\text { lowering of the RyR-mediated Ca }{ }^{2+} \text { leak. }\end{array}$ & $\begin{array}{l}\text { Remppis et al., } 1996 \\
\text { Most et al., } 2006 \\
\text { Pleger et al., } 2007\end{array}$ \\
\hline
\end{tabular}

Table 4. The examples of various proteins involved in calcium signaling studied for gene therapy. 


\subsection{Role of cell cycle activation in gene therapy}

The normal cell passes through the stages of G1-S-G2-M in that orderly sequence as a part of the cell cycle; with a quiescent G0 phase before entering the S phase from G1. This cell cycle is highly subject to strict regulation by a number of molecules that either enhance or retard the progression of the cycle. The two important check-points G1-S and G2-M demand the requirement of a group of proteins called cyclins to overcome them; that do so by combining with a group of cyclin-dependent kinases (CDKs). The expression of cyclins is enhanced by dephosphorylation of $\mathrm{Rb}$ protein; mutations in which are found to be responsible for the ocular tumour retinoblastoma. Similarly, the CDKs are inhibited by the proteins of the Cip/Kip family as well as those of the p16/INK4a locus. A major role is also played by p53 protein, that halts the cell cycle, allowing time for the DNA damage to be rectified; if successful, terminates its own action by inducing autocatalysis through induction of MdM2 and if the DNA damage cannot be repaired, initiates apoptosis. Cell cycle activation is another promising application of gene therapy which results in the induction of endogenous myocardial regeneration. In various pre-clinical set ups it has resulted in activation of the cardiomyocyte cell cycle, thereby limiting the infarct size and improving LV dysfunction. The cyclins and the CDKs are the various candidate genes, the induction of which permits the cell to overcome the endogenous checkpoints and continue with the replication, thus allowing the cardiomyocyte growth. Studies in animals have yielded encouraging results, as listed in the following table; while clinical trials in humans are still awaited (Table 5).

\begin{tabular}{|c|c|c|c|}
\hline $\begin{array}{c}\text { Target } \\
\text { Gene }\end{array}$ & Species & Outcome & Reference \\
\hline Cyclin -A2 & Rats & $\begin{array}{c}\text { Increased border-zone myofilament } \\
\text { density and improved myocardial } \\
\text { function }\end{array}$ & Woo et al., 2006 \\
\hline CDK4 & Rats & Improved left ventricular function & $\begin{array}{c}\text { Tamamori-Adachi } \\
\text { et al., 2008 }\end{array}$ \\
\hline
\end{tabular}

Table 5. The examples of proteins involved in cell cycle studied for gene therapy.

\subsection{Role of $\beta$-adrenergic system in gene therapy}

$\beta$-adrenergic receptor blockers have been shown to exert favorable effects in heart-failure patients. Numerous clinical and experimental studies have shown that molecular targeting of various proteins within the cardiac beta-adrenergic receptor ( $\beta$-ARs) pathway may be beneficial in heart failure. Chronic heart failure due to MI is associated with increased sympathetic discharge. However, this increased sympathetic activity is compensated mechanistically, but is more injurious in the long term. The $\beta$-adrenergic system is affected by multiple modifications including $\beta$-AR down-regulation, up-regulation of $\beta$-AR kinases and increased Gi function leading to $\beta$-AR desensitization and decreased $\beta$-AR signaling activity in heart failure. Several gene-based experiments tested and established that cardiac functions are improved or enhanced by genetic manipulation of the myocardial $\beta$-AR system.

\subsection{1 $\beta 2$-adrenergic receptor overexpression}

Although $\beta 2$-AR overexpression in mouse hearts results in improved systolic and diastolic function; but at significantly high levels, mice developed fibrotic cardiomyopathy and heart 
failure. Moreover, $\beta 2$ signaling stimulates cell-survival and protects myocyte damage from apoptosis. This fact led to the use of $\beta 2$-AR gene delivery in various experimental models of heart failure (Table 6).

\subsubsection{Inhibition of G protein-coupled receptor kinases (GRKs)}

Homologous desensitization (agonist dependent) is mediated by $G$ protein-coupled receptor kinases (GRKs). GRK-2 upregulation is responsible for $\beta$-AR desensitization in heart failure and these kinases dampen the interaction between $\beta$-receptors and their $G$ proteins. In addition, $\beta$-ARKct is a peptide within the carboxy terminus of GRK2 that inhibits GRK-2 mediated $\beta$-AR desensitization. $\beta$ ARKct gene transfer to isolated failing human cardiomyocytes improved their contractile function.

\subsubsection{Adenylatecyclase type 6}

$\beta$-AR stimulation activates adenylate cyclase (AC) through G-protein activation and AC then activates protein kinases to exert its downstream effects. AC6 is the predominant cardiac isoform and its overexpression in cardiac tissue leads to increased left ventricle contractility and function.

\begin{tabular}{|c|c|c|c|}
\hline $\begin{array}{l}\text { Target } \\
\text { Gene }\end{array}$ & Species & Outcome & References \\
\hline$\beta$-ARs & $\begin{array}{l}\text { AdV } \beta-A R \\
\text { intracorona } \\
\text { ry delivery } \\
\text { mice }\end{array}$ & Enhanced cardiac function. & Shah et al., 2000 \\
\hline \multirow[t]{2}{*}{$\begin{array}{l}\text { Inhibition } \\
\text { of GRK- } \\
2 \text { by } \\
\beta A R K c t \\
\text { gene } \\
\text { transfer }\end{array}$} & $\begin{array}{l}\text { Isolated } \\
\text { failing } \\
\text { human } \\
\text { cardiomyo } \\
\text { cytes }\end{array}$ & Improved their contractile function. & $\begin{array}{l}\text { Jameel \& Zhang, } \\
2009\end{array}$ \\
\hline & $\begin{array}{l}\text { Intracorona } \\
\text { ry delivery } \\
\text { of } \mathrm{AdV} \text { - } \\
\beta \mathrm{ARKct} \text { in } \\
\text { mice }\end{array}$ & Improved cardiac function post-MI. & $\begin{array}{c}\text { Iaccarino et al., } \\
1998\end{array}$ \\
\hline $\begin{array}{l}\text { Adenylate } \\
\text { cyclase } \\
\text { type } 6\end{array}$ & $\begin{array}{l}\text { AdV-AC6 } \\
\text { gene } \\
\text { delivery in } \\
\text { pigs }\end{array}$ & Improved LV contractility and function. & Lai et al., 2004 \\
\hline
\end{tabular}

Table 6. Proteins involved in $\beta$-adrenergic system studied for gene therapy.

\section{Clinical aspects}

The human quest and efforts to expand the boundaries of his knowledge into the arena of gene therapy is endless. Genes responsible for cardiovascular events or diseases, myocardial 


\begin{tabular}{|c|c|c|c|}
\hline Clinical Trial & $\begin{array}{c}\text { Sample } \\
\text { size }= \\
\mathrm{n}\end{array}$ & Outcome & References \\
\hline $\begin{array}{c}\text { Intramyocardial } \\
\text { injection of adenovirus } \\
\text { (Ad.VEGF-121) by } \\
\text { thoracotomy \& CABG / } \\
\text { by minimally invasive } \\
\text { thoracotomy }\end{array}$ & 21 & $\begin{array}{l}\text { Both groups showed reduction in } \\
\text { angina but no improvement in } \\
\text { exercise duration. } \\
\text { Proper conclusions could not be } \\
\text { drawn due to absence of control } \\
\text { group. }\end{array}$ & $\begin{array}{c}\text { Rosengart et } \\
\text { al., } 1999\end{array}$ \\
\hline $\begin{array}{l}\text { Injection of ph.VEGF- } \\
165 \text { into LV } \\
\text { myocardium by } \\
\text { minimally invasive } \\
\text { thoracotomy }\end{array}$ & 20 & $\begin{array}{c}\text { Reduction in angina and } \\
\text { nitroglycerine use in } 60 \text { days in all } 5 \\
\text { patients. } \\
\text { Results limited because of a small } \\
\text { sample size and absence of controls. } \\
\text { Reduction in angina and } \\
\text { nitroglycerine use in } 90 \text { days in } 16 \\
\text { out of } 20 \text { patients. } \\
\text { Results limited due to absence of } \\
\text { controls. }\end{array}$ & $\begin{array}{l}\text { Losordo et } \\
\text { al., } 1998\end{array}$ \\
\hline $\begin{array}{l}\text { Administration of } \\
\text { VEGF-165 }\end{array}$ & 20 & $\begin{array}{c}\text { Significant symptomatic } \\
\text { improvement in patients with } \\
\text { inoperable CAD }\end{array}$ & $\begin{array}{c}\text { Symes et al., } \\
1999\end{array}$ \\
\hline $\begin{array}{l}\text { Catheter-mediated } \\
\text { VEGF } \\
\text { plasmid/liposome } \\
(\mathrm{P} / \mathrm{L}) \text { gene transfer }\end{array}$ & 15 & $\begin{array}{l}\text { Catheter-mediated intracoronary } \\
\text { gene transfer performed after } \\
\text { angioplasty significantly prevents } \\
\text { restenosis and myocardial ischemia. }\end{array}$ & $\begin{array}{l}\text { Laitinen et } \\
\text { al., } 2000\end{array}$ \\
\hline $\begin{array}{l}\text { Percutaneous catheter- } \\
\text { based gene transfer of } \\
\text { naked plasmid DNA for } \\
\text { VEGF-2 to LV } \\
\text { myocardium }\end{array}$ & 19 & $\begin{array}{l}\text { Decrease in angina \& improvement } \\
\text { in symptoms. } \\
\text { Drawback: sample size is low. }\end{array}$ & $\begin{array}{l}\text { Losordo et } \\
\text { al., } 2002\end{array}$ \\
\hline
\end{tabular}

Table 7. Clinical trials for gene therapy in myocardial infarction. Ad.VEGF-121: Adenovirus encoding Vascular Endothelial Growth Factor-121; ph.VEGF-165: Plasmid vector encoding Vascular Endothelial Growth Factor-165; Ad.FGF-4: Adenovirus encoding Fibroblast Growth Factor-4; LV: Left ventricle; LacZ: Z gene of lac operon; HIF-a: Hypoxia-Inducible Factor-a.

infarction in particular, have been identified and targeted as a means of curative approach. An example can be illustrated of the study conducted by Doney and his colleagues (Doney et al., 2009) who identified an allele of rs9939609 gene, also referred to as FTO (Fat mass and obesity associated) gene. This gene increased the risk of Type II diabetes mellitus, an atherogenic lipid profile (including decreased high density lipoprotein and increased triglycerides) and myocardial infarction. This allele presents a target which if suitably replaced by the wild type can decrease the risks for all the above conditions.

One of the main drawbacks for designing gene therapy for myocardial infarction is the ethical concerns pertaining to the selection of participants. The participants are among those who have suffered an attack of myocardial infarction and conducting studies on such a 
cohort of patients with a risk of failure of therapy raises a substantial debate. Apart from this, the set-up for these studies also demands technical and financial support on a tremendously large scale. It is for these very precise reasons that a large number of these studies have not yet been conducted so far and hence the relative paucity of these studies in literature as compared to other studies. However the recent advances in the study of human genome and identification of genes associated with the risk factors, pathogenesis as well as outcome of myocardial infarction, has given a great impetus for designing clinical trials for gene therapy. As a result, a good number of trials are currently underway, for instance, the endocardial gene therapy with VEGF-D for severe coronary heart disease.

Apart from the ethical and financial constraints, there are practical difficulties as well, for instance, the delivery of viral particles in to the human body may stimulate the immune system that stimulates the T lymphocytes and cytokines to clear the virus. The naked DNA administered may be lysed by DNAses present in the serum. The permeability of the naked DNA across cell membranes is also restricted, necessitating the requirement for intracellular transfer. On the other hand, an intravenous injection may result in transfection of other tissues apart from the heart and lodgement of the vectors in other organs such as the lung or kidney. To circumvent these possibilities, the technology required for gene transfer needs to be highly advanced and sophisticated to ensure that the vector containing the therapeutic gene transfects only the desired myocardial cells. An example of such technology is the UTMD (ultrasound targeted microbubble destruction), in which ultrasound contrast agents used as gas microbubbles, are packed with the therapeutic gene containing DNA and are destroyed within the myocardium by subjecting them to high ultrasound frequency. A very high number of clinical trials have not been conducted for gene therapy in MI. Some of the clinical trials that have been undertaken in this regard are enlisted in table 7 .

\section{Limitations of gene therapy}

As with most experimental therapies, safety of gene therapy for ischemic heart disease is of paramount importance. Though clinical trials have shown short-term safety, long-term surveillance over a period of decades is lacking. The question still remains as to which therapy benefits what sub-population of patients. Inclusion of a wide selection of patients in studies over time may lead to improvement in subgroups of patients if not the entire population. Confounding factors such as use of concurrent medications and concurrent medical conditions lead to difficulty in standardizing groups of patients. Objective end points of assessment need to be used uniformly as exercise testing may be subjective and is victim to high variability in the same patient on different days. Frequency of testing for objective improvements may need to be ramped up as the effects of therapeutic genes may have abated at the time of a single test. Another surprising factor that confounded results of clinical trials was a strong placebo effect. This might be minimized when objective and not subjective end points are used when assessing outcomes. Drug related issues such as the dose, gene transfection efficiency, pharmacokinetics and pharmacodynamics of individual therapies are valid as these may differ in different populations of patients. Also costeffectiveness analysis has to be considered, as production of gene therapy vectors itself is cumbersome, requires specialized equipment and personnel and the administration of gene therapy is invasive in nature. Besides, specific gene therapy may not compare favourably to available pharmacological agents in use to treat ischemic heart disease in terms of costbenefit ratio. 


\section{Conclusions and future directions}

As of now, the applications of gene therapy for treatment of human diseases, including cardiovascular conditions, though appears to be extremely promising and fascinating, is, in the true sense of the term, still in its infancy. A vast magnitude of studies, not only on humans, but further studies on animal models, are still necessary to validate the practical efficacy of this widely-sought-after approach. Overcoming the practical difficulties discussed above is not an easy task and a tremendous amount of finance and infrastructure is an inevitable requirement to achieve this goal. In spite of that, there still remains a possibility that the gene therapeutically administered may not be expressed in the target individual, subject to an inability of the vectors to reach the target tissue, metabolism of the vectors by the immune system or the presence of other intracellular substances that may exert a negative regulation on the gene expression.

It is possible that extensive use of small animals for pre-clinical research may have led to excessive enthusiasm too early. Gene therapy testing on larger animals may provide a better insight into the true efficacy of specific therapies.

However, these shortcomings should not prove to be a permanent obstacle as the prospects offered by the advent of gene therapy have been extremely fascinating. The elucidation of the human genome has exposed a vast array of genes that are responsible for umpteen number of diseases; such as cystic fibrosis, familial hypercholesterolemia, Lesch-Nyhan syndrome, Alzheimer's disease, Parkinson's disease, Duchenne muscular dystrophy, multiple sclerosis and others. These genes offer potential candidates for regulation that can alter the course of the disease as against the current medications available that mainly provide symptomatic relief. Thus, the future for gene therapy appears to be very bright. A good political establishment to provide the necessary infrastructure and monetary support might go a long way to circumvent the existing shortcomings and empower gene therapy to grow as the most preferred and successful therapeutic approach to most of the diseases that were considered incurable till the past few decades.

\section{References}

Abunasra, H.J.; Smolenski, R.T.; Morrison, K. et al. (2001). Efficacy of adenoviral gene transfer with manganese superoxide dismutase and endothelial nitric oxide synthase in reducing ischaemia and reperfusion injury. European Journal of CardioThoracic Surgery 20, 153-158.

Agata, J.; Chao, L. \& Chao, J. (2002). Kallikrein gene delivery improves cardiac reserve and attenuates remodeling after myocardial infarction. Hypertension 40, 653-659.

Ahmet, I.; Sawa, Y.; Iwata, K. et al. (2002). Gene transfection of hepatocyte growth factor attenuates cardiac remodeling in the canine heart: a novel gene therapy for cardiomyopathy. The Journal of Thoracic and Cardiovascular Surgery 124, 957-963.

Ahmet, I.; Sawa, Y.; Yamaguchi, T. et al. (2003). Gene transfer of hepatocyte growth factor improves angiogenesis and function of chronic ischemic myocardium in canine heart. The Annals of Thoracic Surgery 75, 1283-1287.

American Heart Association, 2003, Heart and Stroke facts 2002: Statistical supplement. Dallas, USA

Aoki, M.; Morishita, R.; Taniyama, Y. et al. (2000) Angiogenesis induced by hepatocyte growth factor in non-infarcted myocardium and infarcted myocardium: up- 
regulation of essential transcription factor for angiogenesis, ets. Gene Therapy 7, 417-27.

Arner, E. \& Holmgren, A. (2000). Physiological functions of thioredoxin and thioredoxin reductase. European Journal of Biochemistry 267, 6102 - 6109.

Berry, M.F.; Pirolli, T.J.; Jayasankar, V. et al. (2004). Targeted overexpression of leukemia inhibitory factor to preserve myocardium in a rat model of postinfarction heart failure. The Journal of Thoracic and Cardiovascular Surgery 128, 866-875.

Borgstahl, G.E.; Parge, H.E.; Hickey, M.J. et al. (1996). Human mitochondrial manganese superoxide dismutase polymorphic variant Ile58Thr reduces activity by destabilizing the tetrameric interface. Biochemistry 35, 4287 - 4297.

Bull, D.A.; Bailey, S.H.; Rentz, J.J. et al. (2003) Effect of Terplex/ VEGF-165 gene therapy on left ventricular function and structure following myocardial infarction. VEGF gene therapy for myocardial infarction. Journal of Controlled Release 93, 175-181.

Cao, X.; Antonyuk, S.V.; Seetharaman, S.V. et al. (2008). Structures of the G85R variant of SOD1in familial amyotrophic lateral sclerosis. Journal of Biological Chemistry 283, 16169 - 16177.

Kumar, V.; Abbas, A.K.; Fausto, N. \& Aster, J.C. (2010). Cellular Responses to Stress and Toxic Insults: Adaptation, Injury and Death. Robbins and Cotran's Pathologic Basis of Disease, Ed. 8, pp22-24, ISBN 978-81-312-2491-5; Pennsylvania, USA.

Chatterjee, S.; Stewart, A.S.; Bish, L.T. et al. (2002). Viral gene transfer of the antiapoptotic factor Bcl-2 protects against chronic postischemic heart failure. Circulation 106 (12 Suppl 1), I212-I217.

Chatterjee, S.; Bish, L.T.; Jayasankar, V. et al. (2003). Blocking the development of postischemic cardiomyopathy with viral gene transfer of the apoptosis repressor with caspase recruitment domain. The Journal of Thoracic and Cardiovascular Surgery 125, 1461-1469.

Chen, Z.; Siu, B.; Ho, Y. et al. (1998). Overexpression of MnSOD protects against Myocardial Ischemia/Reperfusion Injury in Transgenic Mice. Journal of Molecular and Cellular Cardiology 30, 2281 - 2289.

Cho, K.R.; Choi, J.S.; Hahn, W. et al. (2008). Therapeutic angiogenesis using naked DNA expressing two isoforms of the hepatocyte growth factor in a porcine acute myocardial infarction model. European Journal of Cardio-thoracic Surgery 34, 857-863.

Choi, J.S.; Kim, K.B.; Han, W. et al. (2006). Efficacy of therapeutic angiogenesis by intramyocardial injection of pCK-VEGF165 in pigs. The Annals of Thoracic Surgery $82,679-686$.

Cittadini, A.; Monti, M.G.; Iaccarino, G. et al. (2006). Adenoviral gene transfer of Akt enhances myocardial contractility and intracellular calcium handling. Gene Therapy 13, 8-19.

del Monte F, Harding SE, Schmidt U. et al. (1999). Restoration of contractile function in isolated cardiomyocytes from failing human hearts by gene transfer of SERCA2a. Circulation 100, 2308-2311.

del Monte, F.; Williams, E.; Lebeche, D. et al. (2001a). Improvement in survival and cardiac metabolism after gene transfer of sarcoplasmic reticulum $\mathrm{Ca}\left(2^{+}\right)$-ATPase in a rat model of heart failure. Circulation 104, 1424-1429.

del Monte, F.; Hajjar, R.J. \& Harding, S.E. (2001b). Overwhelming evidence of the beneficial effects of SERCA gene transfer in heart failure. Circulation Research 88, E66-E67. 
del Monte, F.; Harding, S.E.; Dec, G.W. et al. (2002). Targeting phospholamban by gene transfer in human heart failure. Circulation 105, 904-907.

Doney, A.S.; Dannfald, J.; Kimber, C.H. et al. (2009). The FTO gene is associated with an Atherogenic Lipid Profile and Myocardial Infarction in patients with type 2 diabetes mellitus. Circulation: Cardiovascular Genetics 2, 255 - 259.

Edelberg, J.M.; Lee, S.H.; Kaur, M. et al. (2002). Platelet-derived growth factor-AB limits the extent of myocardial infarction in a rat model: feasibility of restoring impaired angiogenic capacity in the aging heart. Circulation 105, 608-613.

Ferrarini, M.; Arsic, N.; Recchia, F.A. et al. (2006). Adeno-associated virus-mediated transduction of VEGF165 improves cardiac tissue viability and functional recovery after permanent coronary occlusion in conscious dogs. Circulation Research 98, 954961.

Funatsu, T.; Sawa, Y.; Ohtake, S. et al. (2002). Therapeutic angiogenesis in the ischemic canine heart induced by myocardial injection of naked complementary DNA plasmid encoding hepatocyte growth factor. The Journal of Thoracic and Cardiovascular Surgery 124, 1099-1105.

Gao, M.H.; Lai, N.C.; McKirnan, M.D. et al. (2004). Increased regional function and perfusion after intracoronary delivery of adenovirus encoding fibroblast growth factor 4: report of preclinical data. Human Gene Therapy 15, 574-587.

Giordano, F.J.; Ping, P.; McKirnan, M.D. et al. (1996). Intracoronary gene transfer of fibroblast growth factor-5 increases blood flow and contractile function in an ischemic region of the heart. Nature Medicine 2, 534-539.

Hao, X.; Månsson-Broberg, A.; Gustafsson, T. et al. (2004a). Angiogenic effects of dual gene transfer of bFGF and PDGF-BB after myocardial infarction. Biochemical and Biophysical Research Communications 315, 1058-1063.

Hao, X.; Månsson-Broberg, A.; Blomberg, P. et al. (2004b). Angiogenic and cardiac functional effects of dual gene transfer of VEGF-A165 and PDGF-BB after myocardial infarction. Biochemical and Biophysical Research Communications 322, 292-296.

Hao, X.; Mansson-Broberg, A.; Grinnemo, K.H. et al. (2007). Myocardial angiogenesis after plasmid or adenoviral VEGF-A (165) gene transfer in rat myocardial infarction model. Cardiovascular Research 73, 481-487.

Hirsch, J.C.; Borton, A.R.; Albayya, F.P. et al. (2004). Comparative analysis of parvalbumin and SERCA2a cardiac myocytegene transfer in a large animal model of diastolic dysfunction. American Journal of Physiology. Heart and Circulatory Physiology 286, H2314-2321.

Horvath, K.A.; Doukas, J.; Lu, C.Y. et al. (2002). Myocardial functional recovery after fibroblast growth factor 2 gene therapy as assessed by echocardiography and magnetic resonance imaging. The Annals of Thoracic Surgery 74, 481-486.

Hsieh, P.C.; MacGillivray, C.; Gannon, J. et al. (2006). Local controlled intra myocardial delivery of platelet-derived growth factor improves post infarction ventricular function without pulmonary toxicity. Circulation 114, 637-644.

Iaccarino, G.; Tomhave, E.D.; Lefkowitz, R.J. et al. (1998). Reciprocal in vivo regulation of myocardial $G$ protein-coupled receptor kinase expression by $\beta$-adrenergic receptor stimulation and blockade. Circulation 98, 1783-1789. 
Jacquier, A.; Higgins, C.B.; Martin, A.J. et al. (2007). Injection of adeno associated viral vector encoding vascular endothelial growth factor gene in infarcted swine myocardium: MR measurements of left ventricular function and strain. Radiology 245, 196-205.

Jameel, M.N. \& Zhang, J. (2009). Heart failure management: the present and the future. Antioxidants and Redox Signaling 11, 1989-2010.

Jayasankar, V.; Woo, Y.J.; Bish, L.T. et al. (2003). Gene transfer of hepatocyte growth factor attenuates postinfarction heart failure. Circulation 108 (Suppl 1), II230-II236.

Jin, H.; Wyss, J.M.; Yang, R. et al. (2004). The therapeutic potential of hepatocyte growth factor for myocardial infarction and heart failure. Current Pharmaceutical Design 10, 2525-2533.

Jin, Z.Q.; Zhang, J.; Huang, Y. et al. (2007). A sphingosine kinase 1 mutation sensitizes the myocardium to ischemia/reperfusion injury. Cardiovascular Research 76, 41-50.

Kadambi, V.J.; Ponniah, S.; Harrer, J.M. et al. (1996). Cardiac-specific overexpression of phospholamban alters calcium kinetics and resultant cardiomyocyte mechanics in transgenic mice. Journal of Clinical Investigation 97, 533-539.

Kaye, D.M.; Preovolos, A.; Marshall, T. et al. (2007). Percutaneous cardiac recirculationmediated gene transfer of an inhibitory phospholambanpeptide reverses advanced heart failure in large animals. Journal of the American College of Cardiology 50, 253260.

Kiriazis, H. \& Kranias, E.G. (2000). Genetically engineered models with alterations in cardiac membrane calcium-handling proteins. Annual Review of Physiology 62, 321-351.

Kondo, I.; Ohmori, K.; Oshita, A. et al. (2004). Treatment of acute myocardial infarction by hepatocyte growth factor gene transfer: the first demonstration of myocardial transfer of a "functional" gene using ultrasonic microbubble destruction. Journal of the American College of Cardiology 44, 644-653.

Krausgrill, B.; Vantler, M.; Burst, V. et al. (2009). Influence of cell treatment with PDGF-BB and reperfusion on cardiac persistence of mononuclear and mesenchymal bone marrow cells after transplantation into acute myocardial infarction in rats. Cell Transplantation 18, 847-853.

Kusano, K.F.; Pola, R.; Murayama, T. et al. (2005). Sonic hedgehog myocardial gene therapy: tissue repair through transient reconstitution of embryonic signaling. Nature Medicine 11, 1197-204.

Lahteenvuo, J.E.; Lahteenvuo, M.T.; Kivela, A. et al. (2009). Vascular endothelial growth factor-B induces myocardium-specific angiogenesis and arteriogenesis via vascular endothelial growth factor receptor-1- and neuropilin receptor-1-dependent mechanisms. Circulation 119, 845-856.

Lai, N.C.; Roth, D.M. \& Gao, M.H. (2004). Intracoronaryadenovirus encoding adenylyl cyclase VI increases leftventricular function in heart failure. Circulation 110, 330336.

Lai, Z.F.; Chen, Y.Z.; Feng, L.P. et al. (2008). Overexpression of TNNI3K, a cardiac-specific MAP kinase, promotes P19CL6-derived cardiac myogenesis and prevents myocardial infarction-induced injury. American Journal of Physiology. Heart and Circulatory Physiology 295, H708-716.

Laitinen, M.; Hartikainen, J. \& Eranen, J. (2000). Catheter-mediated VEGF-gene transfer to human coronary artery after angioplasty. Human Gene Therapy 110, $263-270$. 
Lee, L.Y.; Patel, S.R.; Hackett, N.R. et al. (2000). Focal angiogen therapy using intramyocardial delivery of an adenovirus vector coding for vascular endothelial growth factor 121. The Annals of Thoracic Surgery 69, 14-23

Lee, M.; Rentz, J.; Bikram, M. et al. (2003). Hypoxia-inducible VEGF gene delivery to ischemic myocardium using water-soluble lipopolymer. Gene Therapy 10, 15351542.

Li, Q.; Bolli, R.; Qiu, Y. et al. (2001). Gene Therapy with Extracellular Superoxide Dismutase protects conscious rabbits against Myocardial Infarction. Circulation 103, 1893 1898.

Li, Y.; Takemura, G.; Kosai, K. et al. (2003). Postinfarction treatment with an adenoviral vector expressing hepatocyte growth factor relieves chronic left ventricular remodeling and dysfunction in mice. Circulation 107, 2499-506.

Losordo, D.W.; Vale, P.R.; Hendel, R.C. et al. (2002). Phase 1/2 placebo-controlled, doubleblinded, dose-escalating trial of myocardial VEGF-2 Gene Transfer by Catheter Delivery in patients with chronic Myocardial Infarction. Circulation 105, 2012-2018.

Losordo, D.W.; Vale, P.R.; Symes, J.F. et al. (1998). Gene therapy for myocardial angiogenesis: initial clinical results with direct injection of ph.VEGF-165 as a sole therapy for myocardial ischemia. Circulation 98, 2800 - 2804.

Lu, H.; Xu, X.; Zhang, M. et al. (2007). Combinatorial protein therapy of angiogenic and arteriogenic factors remarkably improves collaterogenesis and cardiac function in pigs. Proceedings of the National Academy of the Sciences of the USA. 104, 12140-12145.

Mack, C.A.; Patel, S.R.; Schwarz, E.A. et al. (1998). Biologic bypass with the use of adenovirus-mediated gene transfer of the complementary deoxyribonucleic acid for vascular endothelial growth factor 121 improves myocardial perfusion and function in the ischemic porcine heart. The Journal of Thoracic and Cardiovascular Surgery 115, 168-176.

Maines, M.D. (1988). Heme oxygenase: Function, multiplicity, regulatory mechanisms, and clinical application. FASEB J 2, 557 - 2568.

McCord, J.M. \& Fridovich, I. (1988). Superoxide dismutase, the first twenty years (1968 1988). Free Radical Biology and Medicine 5, 363 - 369.

Melo, L.G.; Agarwal, R.; Zhang, L. et al. (2002). Gene Therapy Strategy for Long-Term Myocardial Protection using Adeno-Associated Virus- Mediated Delivery of Heme Oxygenase gene. Circulation 105, 602 - 607.

Miao, W.; Luo, Z.; Kitsis, R.N. et al. (2000). Intracoronary, adenovirus-mediated Akt gene transfer in heart limits infarct size following ischemia-reperfusion injury in vivo. Journal of Molecular and Cellular Cardiology 32, 2397-402.

Michiels, C.; Raes, M.; Toussaint, O. et al. (1994). Importance of SE-glutathione peroxidase, catalase and $\mathrm{Cu} / \mathrm{Zn}-\mathrm{SOD}$ for cell survival against oxidative stress. Free Radical Biology and Medicine 17, 235 - 248.

Miyamoto, M.I.; del Monte, F.; Schmidt, U. et al. (1996). Altered expression of the Ca(2+)binding protein S100A1 in human cardiomyopathy. Biochimica et Biophysica Acta 1313, 253-257.

Miyamoto, M.I.; del Monte, F.; Schmidt, U. et al. (2000). Adenoviral gene transfer of SERCA2a improves left-ventricular function in aortic-banded rats in transition to heart failure. Proceedings of the National Academy of the Sciences of the USA 97, 793798 . 
Most, P.; Pleger, S.T.; Volkers, M. et al. (2004). Cardiac adenoviral S100A1 gene deliveryrescues failing myocardium. Journal of Clinical Investigation 114, 1550 -1563.

Most, P.; Seifert, H.; Gao, E. et al. (2006). Cardiac S100A1 protein levels determine contractile performance and propensity toward heart failure after myocardial infarction. Circulation 114, $1258-1268$.

Nabel, E.G.; Plautz, G.; Boyce, F.M. et al. (1989). Recombinant gene expression in vivo within endothelial cells of the arterial wall. Science 244, 1342-1344.

Okubo, S.; Wildner, O.; Shah, M.R. et al. (2001). Gene transfer of heat-shock protein 70 reduces infarct size in vivo after ischemia/reperfusion in the rabbit heart. Circulation 103, 877-881.

Patila, T.; Ikonen, T.; Rutanen, J. et al. (2006). Vascular endothelial growth factor C-induced collateral formation in a model of myocardial ischemia. The Journal of Heart and Lung Transplantation 25, 206-213.

Pleger, S.T.; Most, P.; Boucher, M. et al. (2007). Stable myocardial-specific AAV6-S100A1 gene therapy results in chronic functional heart failure rescue. Circulation 115, 25062515.

Post, M.J.; Sato, K.; Murakami, M. et al. (2006). Adenoviral PR39 improves blood flow and myocardial function in a pig model of chronic myocardial ischemia by enhancing collateral formation. American Journal of Physiology. Regulatory, Integrative and Comparative Physiology 290, R494-500.

Remppis, A.; Greten, T.; Schafer, B.W. et al. (1996). Altered expression of the Ca(2+)-binding protein S100A1 in human cardiomyopathy. Biochimica et Biophysica Acta 1313, 253257.

Rosengart, T.K.; Lee, L.Y.; Patel, S.R. et. al. (1999). Angiogenesis gene therapy: Phase I assessment of direct intramyocardial administration of an adenovirus vector expressing VEGF-121 cDNA to individuals with clinically significant coronary artery disease. Circulation 100, 468-474.

Ruixing, Y.; Jiaquan, L.; Jie, C. \& Dezhai, Y. (2006). Intravenous administration of vascular endothelial growth factor improves cardiac performance and inhibits cardiomyocyte apoptosis. Growth Factors 24, 209-217.

Ruixing, Y.; Jinzhen, W.; Dezhai, Y. et al. (2007). Cardioprotective role of cardiotrophin- 1 gene transfer in a murine model of myocardial infarction. Growth Factors 25, 286294.

Rutanen, J.; Rissanen, T.T.; Markkanen, J.E. et al. (2004). Adenoviral catheter-mediated intramyocardial gene transfer using the mature form of vascular endothelial growth factor-D induces transmural angiogenesis in porcine heart. Circulation 109, 1029-1035.

Samuel, S.M.; Thirunavukkarasu, M.; Penumathsa, S.V. et al. (2010) Thioredoxin-1 gene therapy enhances angiogenic signaling and reduces ventricular remodeling in infarcted myocardium of diabetic rats. Circulation 121, 1244-55.

Shah, A.S.; Lilly, R.E.; Kypson, A.P. et al. (2000). Intracoronary adenovirus-mediated delivery and overexpression of the beta (2)-adrenergic receptor in the heart prospects for molecular ventricular assistance. Circulation 101, 408-14.

Su, H.; Arakawa-Hoyt, J. \& Kan, Y.W. (2002). Adeno-associated viral vector-mediated hypoxia response element-regulated gene expression in mouse ischemic heart model. Proceedings of the National Academy of the Sciences of the USA 99, 9480-9485. 
Sugano, M.; Tsuchida, K.; Hata, T. et al. (2004). In vivo transfer of soluble TNF-alpha receptor 1 gene improves cardiac function and reduces infarct size after myocardial infarction in rats. FASEB J 18, 911-913.

Suzuki, G.; Lee, T.C.; Fallavollita, J.A. et al. (2005). Adenoviral gene transfer of FGF-5 to hibernating myocardium improves function and stimulates myocytes to hypertrophy and reenter the cell cycle. Circulation Research 96, 767-775.

Suzuki, K.; Murtuza, B.; Sammut, I.A. et al. (2002). Heat shock protein 72 enhances manganese superoxide dismutase activity during myocardial ischemia-reperfusion injury, associated with mitochondrial protection and apoptosis reduction. Circulation 106 (12 Suppl 1), 1270-1276.

Symes, J.F.; Losordo, D.W.; Vale, P.R. et. al. (1999). Gene therapy with vascular endothelial growth factor for inoperable coronary artery disease. The Annals of Thoracic Surgery $68,830-837$.

Tamamori-Adachi, M.; Takagi, H.; Hashimoto, K. et al. (2008). Cardiomyocyte proliferation and protection against post-myocardial infarction heart failure by cyclin D1 and Skp2 ubiquitin ligase. Cardiovascular Research 80, 181-90.

Taniyama, Y.; Morishita, R.; Aoki, M. et al. (2002). Angiogenesis and antifibrotic action by hepatocyte growth factor in cardiomyopathy. Hypertension 40, 47-53.

Tenhunen, O.; Soini, Y.; Ilves, M. et al. (2006). p38 Kinase rescues failing myocardium after myocardial infarction: evidence for angiogenic and anti-apoptotic mechanisms. FASEB J 20, 1907-1909.

Tio, R.A.; Tkebuchava, T.; Scheuermann, T.H. et al. (1999). Intramyocardial gene therapy with naked DNA encoding vascular endothelial growth factor improves collateral flow to ischemic myocardium. Human Gene Therapy 10, 2953-2960.

Wang, W.; Yang, Z.J.; Ma, D.C. et al. (2006a). Induction of collateral artery growth and improvement of post-infarct heart function by hepatocyte growth factor gene transfer. Acta Pharmacologica Sinica 27, 555-560.

Wang, L.; Yang, J.; Liu, Z.X. et al. (2006b). Gene transfer of CD151 enhanced myocardial angiogenesis and improved cardiac function in rats with experimental myocardial infarction. Zhonghua Xin Xue Guan Bing Za Zhi 34, 159-163.

Wollmann, E.E.; d'Auriol, L.; Rimsky, L. et al. (1988). Cloning and expression of a cDNA of human thioredoxin. Journal of Biological Chemistry 263, $15506-15512$.

Woo, Y.J.; Panlilio, C.M.; Cheng, R.K. et al. (2006). Therapeutic delivery of cyclin A2 induces myocardial regeneration and enhances cardiac function in ischemic heart failure. Circulation 114, I206-I213.

Yang, Z.; Wang, W.; Ma, D.; et al. (2007). Recruitment of stem cells by hepatocyte growth factor via intracoronary gene transfection in the postinfarction heart failure. Science China Life Sciences 50, 748-752.

Yang, Z.J.; Chen, B.; Sheng, Z. et al. (2010). Improvement of heart function in postinfarct heart failure swine models after hepatocyte growth factor gene transfer: comparison of low-, medium- and high-dose groups. Molecular Biology Reports 37, 2075-2081.

Yla-Hertella, S. \& Martin, J.F. (2000). Cardiovascular gene therapy. Lancet 355, 213-222.

Yockman, J.W.; Choi, D.; Whitten, M.G. et al. (2009). Polymeric gene delivery of ischemiainducible VEGF significantly attenuates infarct size and apoptosis following myocardial infarct. Gene Therapy 16, 127-135. 
Zhang, D.; Gai, L.; Fan, R. et al. (2002). Efficacy and safety of therapeutic angiogenesis from direct myocardial administration of an adenoviral vector expressing vascular endothelial growth factor 165. Chinese Medical Journal 115, 643-648.

Zheng, J.; Shin, J.H.; Xaymardan, M. et al. (2004). Platelet-derived growth factor improves cardiac function in a rodent myocardial infarction model. Coronary Artery Disease 15, 59-64.

Zhu, Y.H.; Ma, T.M. \& Wang, X. (2005). Gene transfer of heat-shock protein 20 protects against ischemia/reperfusion injury in rat hearts. Acta Pharmacologica Sinica 26, 1193-2000.

Zuo, H.; Liu, Z.; Liu, X. et al. (2009). CD151 gene delivery after myocardial infarction promotes functional neovascularization and activates FA signaling. Molecular Medicine 15, 307-315. 


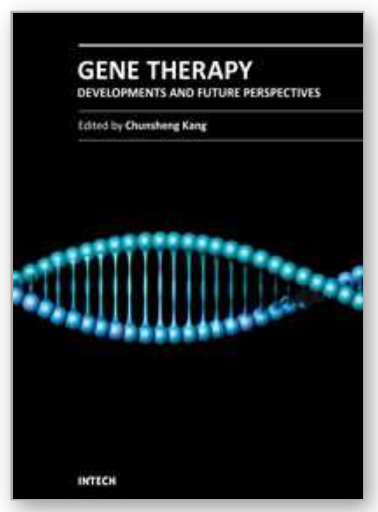

\author{
Gene Therapy - Developments and Future Perspectives \\ Edited by Prof. Chunsheng Kang
}

ISBN 978-953-307-617-1

Hard cover, 356 pages

Publisher InTech

Published online 22, June, 2011

Published in print edition June, 2011

The aim of this book is to cover key aspects of existing problems in the field of development and future perspectives in gene therapy. Contributions consist of basic and translational research, as well as clinical experiences, and they outline functional mechanisms, predictive approaches, patient-related studies and upcoming challenges in this stimulating but also controversial field of gene therapy research. This source will make our doctors become comfortable with the common problems of gene therapy and inspire others to delve a bit more deeply into a topic of interest.

\title{
How to reference
}

In order to correctly reference this scholarly work, feel free to copy and paste the following:

Saurabh Bharti, Ashok Kumar Sharma, Bhaskar Krishnamurthy and Dharamvir Singh Arya (2011). Preclinical and Clinical Prospects of Gene Therapy in Myocardial Infarction, Gene Therapy - Developments and Future Perspectives, Prof. Chunsheng Kang (Ed.), ISBN: 978-953-307-617-1, InTech, Available from:

http://www.intechopen.com/books/gene-therapy-developments-and-future-perspectives/preclinical-and-clinicalprospects-of-gene-therapy-in-myocardial-infarction

\section{INTECH}

open science | open minds

\section{InTech Europe}

University Campus STeP Ri

Slavka Krautzeka 83/A

51000 Rijeka, Croatia

Phone: +385 (51) 770447

Fax: +385 (51) 686166

www.intechopen.com

\section{InTech China}

Unit 405, Office Block, Hotel Equatorial Shanghai

No.65, Yan An Road (West), Shanghai, 200040, China

中国上海市延安西路65号上海国际贵都大饭店办公楼 405 单元

Phone: +86-21-62489820

Fax: $+86-21-62489821$ 
(C) 2011 The Author(s). Licensee IntechOpen. This chapter is distributed under the terms of the Creative Commons Attribution-NonCommercialShareAlike-3.0 License, which permits use, distribution and reproduction for non-commercial purposes, provided the original is properly cited and derivative works building on this content are distributed under the same license. 